\title{
Journal of Asian and African Studies
}

http://jas.sagepub.com

\section{Why Women are at War with Chevron: Nigerian Subsistence Struggles Against the International Oil Industry \\ Terisa E. Turner and Leigh S. Brownhill \\ Journal of Asian and African Studies 2004; 39; 63 \\ DOI: $10.1177 / 0021909604048251$}

The online version of this article can be found at:

http://jas.sagepub.com/cgi/content/abstract/39/1-2/63

\author{
Published by: \\ (A) SAGE \\ http://www.sagepublications.com
}

Additional services and information for Journal of Asian and African Studies can be found at:

Email Alerts: http://jas.sagepub.com/cgi/alerts

Subscriptions: http://jas.sagepub.com/subscriptions

Reprints: http://www.sagepub.com/journalsReprints.nav

Permissions: http://www.sagepub.co.uk/journalsPermissions.nav

Citations http://jas.sagepub.com/cgi/content/refs/39/1-2/63 


\title{
Why Women are at War with Chevron: Nigerian Subsistence Struggles Against the International Oil Industry
}

\author{
Terisa E. Turner* and Leigh S. Brownhill**
}

\begin{abstract}
This study is an inquiry into why women were at war with oil companies in Nigeria and how they internationalized their struggle. Employing the Midnight Notes Collective's concept of "the new enclosures"; Shiva, Mies, and Bennholdt-Thomsen's "subsistence perspective"; and McMurtry's concept of the "civil commons," the study elaborates a "gendered class analysis" to consider the social anatomy of coordinated global actions by producers and consumers of oil. Part one examines the period from July 2002 to February 2003. Nigerian women occupied oil terminals and flow stations and inspired global protests against war and oil companies. Part two considers widespread Nigerian workers' strikes in the period from February 2003 to July 2003. These included work stoppages in transport, the oil industry, and the public service; a two-week seizure by oil workers of four Trans-ocean deep-sea platforms and an eight-day general strike against increases in the price of petroleum products. Part three analyzes the July-September 2003 period. From 10 July 2003 peasant women occupied oil facilities throughout the Delta. As official government neared collapse, village and clan-based organizations assumed much of the responsibility for the oversight of their own communities. By September 2003, insurgents shut down some 40 percent of Nigerian crude oil production capacity. Villagers denied oil companies all physical access to the western Delta. Chevron/Texaco, Shell, other majors and their contractors evacuated their Warri headquarters. The autonomous village organizations, linked to each other through regional solidarity networks, coordinated pan-Delta defense against Nigerian and U.S. military counterinsurgency. The study concludes with an analysis of the roots of insurgent power and direct deals in oil.
\end{abstract}

Keywords: International Oil Industry; Nigeria; subsistence; women

* Associate Professor, University of Guelph, Canada.

** Ph.D. candidate, University of Toronto, Canada.

A version of this study was presented at the 56th Annual United Nations Department of Public Information/Non-Governmental Organization Conference, "Human Security and Dignity: Fulfilling the Promise of the United Nations," United Nations Headquarters, New York, September 8-10, 2003.

The authors wish to acknowledge funding for fieldwork in Nigeria from the Canadian International Development Agency (CIDA) and from the Canadian Social Science and Humanities Research Council.

Copyright (C) 2004 SAGE Publications www.sagepublications.com

(London, Thousand Oaks, and New Delhi)

Vol 39(1-2):63-93. DOI: 10.1177/0021909604048251 


\section{Introduction: Gendered Class Analysis and Nigerian Subsistence Struggles}

From 2002 to 2003, popular movements shut down much of Nigeria's huge oil industry ${ }^{1}$ and faced U.S. military intervention. Women who were at the forefront forged strategic connections with insurgents worldwide. This study examines the period in three parts. First, between July 2002 and February 2003 women's organizations occupied Chevron/Texaco's export terminal and several flow-stations. Their weapon was their nakedness. Naked protests multiplied around the world as women were inspired by the Nigerian example to "bare all" to resist the Bush attack on Iraq. Global boycotts of oil companies proliferated. Second, between February and July 2003, waged Nigerian men joined the peasant women's shutdown of the oil industry by organizing strikes. This mobilization culminated in an eight-day national general strike. Third, in the July to September 2003 period, women again seized oil facilities and shut down the oil companies after oil union "male dealers" sabotaged the general strike. In response to oil company demands the Nigerian and U.S. military intervened.

Three questions are addressed in this study. First, why were women at war with the international oil companies in Nigeria; second, how were anti-oil company campaigns internationalized by women; and, third, with what implications? We begin with a brief treatment of the theoretical framework within which we pose these questions.

First, women are at the forefront of social movements because, despite their being largely unwaged, capital exploits them as it commodifies and uses up "free" nature, social services, built space, and the production of paid and unpaid work (Benjamin and Turner 1992; Brownhill and Turner 2004). All of these "values" are integral to the subsistence or life-centered political economy in which the needs of all are addressed through collective, cooperative, and autonomous activity including producer-organized trade or direct deals (Bennholdt-Thomsen and Mies 1999). Communal land-holding and social relations essential to such a life-centered "civil commons" (McMurtry 2001; 2002) remain resilient in much of the Niger Delta. Oil company operations since 1957 have been destroying the social and physical basis of subsistence (Turner 2001). In 2002 women who are responsible for much of the farming, fishing, feeding, and life sustenance stood up against corporate destruction.

An examination of Nigerian women's occupation and shut-down of oil company facilities in the Niger Delta reveals a pattern of resistance involving two distinct social constructions. Women first broke up "male deals" between some of their own menfolk and personnel of the oil companies, unions, and state. Second, they formed alliances with other men, often their grandsons, and in this "gendered class alliance," successfully evicted the world's largest corporations from their land (Nore and Turner 1980; Turner 1997; Turner et al. 2001). Both of these social de- and re-constructions had national and international expressions. The global reach of cross-class (and often cross-race) "male deals" 
is immediately apparent in the oil industry. In breaking these, Nigerian women built international solidarities and systemic coordination between women and men similarly pitted against the commodification and war brought by oil majors and their corporate-state allies. In sum, to theorize women's war against big oil is to recognize the erasure of subsistence that corporate commodification entails and both the imperative and the capacities of life-producers to stand against it.

The second question - how were international solidarities forged and what is their anatomy? - is here theorized by reference to the systemic, global realities of capitalist organization and markets. The international oil companies bring two (among several) groups of people - those resident on oil reserves and those who consume oil - into one organization (i.e. the organization of the oil corporations themselves and the oil market that they define). Because the oil companies bring these two groups into one global organization; the groups, by acting together, have the power to destroy the corporations by simultaneously denying them crude oil and product purchases. When residents of oil producing communities stop production at the same time as consumers boycott oil companies by refusing to buy their products, the two groups engage in a simultaneous global "production-consumption oil strike." Such a strike has the potential to annihilate the capacities of oil companies to make profits or exercise the power of accumulation. The crucial point here is that the popular organization with this potential to annihilate capital is not "the party," or "the forum." Rather, it is the international organization of the oil corporations themselves and of the oil market that they define. Also embraced within this organization are those engaged in the work of social reproduction and those engaged in the defense and restoration of nature (Dyer-Witheford 1999).

This conception challenges those constructions of "globalization from below" that are limited to liberal declarations or protestations for reform. A much more fertile form of anti-imperial, transformational "globalization from below" was promoted by Nigerian women who, in defending their subsistence life economy, denied strategic crude oil to globally dominate capital. Their explicitly feminist actions provoked women outside of Nigeria to defend subsistence as life-affirmation in the context of global anti-war mobilization. This historically unprecedented world-wide "no to war" movement boosted already existing campaigns to boycott the oil companies which were, at the same time, facing shutdowns in Nigeria as women and their rural allies denied crude oil to the majors. This embryonic world-scale production-consumption oil strike foreshadows globally coordinated strikes and boycotts in the future that will not only shut down oil corporations, but also re-start the petroleum system on a new, subsistence-positive basis. The systemic impetus to globalization from below revealed by the Nigerian insurgency is embodied in the corporate organizational and oil market ties that bind together all of the world's people engaged in producing and consuming oil. The exploited, waged, and unwaged are "organized, united, and 
disciplined" by the "process of production itself" (Marx [1887] 1967: 763). By privileging waged workers, most critical analysts (for example, Fagan 2002) have silenced or misconstrued the essential powers of the unwaged in this new crystallization of social forces asserting a global "life economy civil commons" (McMurtry 2002). The hitherto silenced actors in the system of oil company organization and markets are the women who live in the communities built over hydrocarbon reserves. ${ }^{2}$ Their paramount strategic importance is the reason for their silencing. During 2002 to 2003 Nigerian peasant women broke this silence and bequeathed a gift to humanity in the form of a tremendous impetus toward a world transformed.

What were the implications of the women's internationalized war against the oil companies? This third question can be pursued by theorizing "direct deals." We saw earlier how producer-consumer oil strikes have the potential to deny corporations their profits. Those who engage in producerconsumer oil strikes can take one further step. They can use their control over physical crude oil production sites, on the one hand, and their control over consumption on the other, to negotiate direct deals for the sale and purchase of oil. The crucial point here is that the very organization bequeathed by large corporations can be appropriated by producers and consumers and used against profit and for life support. This takes us to the connections between subsistence and capitalist relations. Those who live on oil reserves, such as the Niger Delta women and their allies, took control of oil facilities to defend and extend a commoning way of life, that is, a political economy which supports life for all. They thereby entered into oil companyorganized alliances with people elsewhere who were attacking the same oil companies through other means, especially boycotts. Through these alliances, direct deals can be negotiated so as to provide those defending subsistence with the means to succeed. Because these direct deals are autonomously organized for mutual benefit, they can support the building of subsistence by both parties involved. This globalized defense, re-invention, and building of subsistence is the central implication of the women's internationalized war against the oil companies.

This vision of revolutionary transformation involves the selective merging of two sets of social relations. On the one hand, the organization of transnational corporations is used by those it organizes to support life instead of profits. This use signals a shift in power within corporate organizations in favor of "commoners." This shift in power gives "commoners" social relations which are global. On the other hand, this set of social relations, extracted from capitalist firms and markets, is merged with selected subsistence social relations in those autonomous communities that seek to re-invent a directly democratic commons at both the local and global levels. 


\section{Part 1. Women Seize Oil Facilities: July 2002 to February 2003}

"We no go 'gree o, we no go 'gree, Chevron people we no go 'gree!"3 (We do not agree, we never agreed, Chevron, we are never going to agree!)

On July 8, 2002, after Chevron/Texaco ignored their June correspondence, some 600 women occupied the U.S. oil giant's 450,000 barrels a day (b/d) Escravos export terminal and tank yard. In their ten-day takeover, the Itsekiri women negotiated 26 demands with corporate management. These included a demand that the government and oil companies meet with rural women and establish a permanent tripartite body (multinationals, state, and women) for the resolution of problems related to oil operations. They signed a memorandum of understanding committing Chevron/Texaco to the upgrading of 15 members of the communities who are contract staff to permanent staff status; the employment of one person from each of the five Ugborodo villages every year; the building of one house each for the elders-the Oloja Ore and the Eghare-Aja-in the communities; provision of vital infrastructure; a monthly allowance of at least N50,000 (U.S.\$375; 1 Naira = U.S.\$.0075) for the elderly aged 60 years and above; and the establishment of income generating schemes (Chevron/Texaco 2003; Okon and Ola 2002). However, the most fundamental demand, that Chevron/Texaco must go, was not countenanced by the company negotiators.

Why were women "at war with Chevron?" Christiana Mene of the Escravos Women Coalition explained:

We want Chevron to employ our children. If Chevron does that we the mothers will survive, we will see food to eat. Our farms are all gone, due to Chevron's pollution of our water. We used to farm cassava, okro, pepper and others. Now all the places we've farmed are sinking, we cannot farm. We cannot catch fishes and crayfish. That is why we told Chevron that Escravos women and Chevron are at war. (Abiola 2002)

International petroleum corporations had reduced the once-rich subsistence economy of the Niger Delta to a polluted wasteland. Women could no longer train their children in peasant pursuits nor look forward to being fed in their old age. Because the oil companies had imposed a fundamental "death economy" on the Delta's seven million people, the women warriors demanded the majors get out completely. They exposed their naked bodies, and most particularly their vaginas, to impose on oil company male dealers "social death" through ostracization, which was widely believed to lead to actual demise. Death was imminent, as sub-commandante Marcos observed, a "regular guest at the table," because the majors had destroyed subsistence. This imminence produced in the women warriors a fearless emotional state of existential liberation, a willingness to die in the cause of expelling Chevron/Texaco, Shell, Exxon/Mobil, and the others. As Queen Uwara, deputy chairperson of the Escravos Women Coalition stated: 
A mother gets old someday, she becomes weak, the same with the father. It is your son and daughter who will be feeding you. If our children are not given work then the mothers cannot survive. They employ other tribes to work here, this time we cannot allow this kind of situation ... Chevron brought soldiers and police to threaten us when we were at Chevron yard. If Chevron wants to kill us, we are no longer afraid. We women have taken over the yard. But we are not afraid because Chevron is on our land. All we want is for Chevron to leave our land. (Environmental Rights Action [hereafter ERA] 2002a) ${ }^{4}$

The women's bold strike at Chevron/Texaco's export terminal immediately inspired at least 12 additional takeovers. Even before the Escravos group concluded negotiations, well over 1,000 women occupied six Chevron/Texaco flow stations including Abiteye, Makaraba, Otuana, and Olera Creek (Wamala 2002: 38). One hundred women paddled a massive canoe five miles into the high seas to take over the company's production platform in the Ewan oilfield. Chevron/Texaco evacuated its staff, shut down production and refused to negotiate with the women because, according to the U.S. major, "they are not from our host community" (International Oil Daily [hereafter IOD] 2002b). The positive results of the women's takeovers encouraged youth to occupy six Shell flow stations in western Niger Delta on September 20, 2002 (IOD 2002d).

On September 26, 2002, in the context of growing anti-war activism, Nigeria's Environmental Rights Action, Project Underground and the Ecuadorian affiliate of OilWatch International called for a boycott against Chevron/Texaco:

to punish this company for the environmental damages and the human rights abuses committed during its operations in Nigeria and Ecuador. Chevron-Texaco will face trials for its impacts in Nigeria and Ecuador. These countries' organizations use boycott as an instrument of pressure against the company, to make it remember that whatever is polluted must be cleaned up. At times when transnational companies frame up regimes of impunity for themselves, we must join efforts to punish companies with our protest, and our vow of censorship by not consuming these companies' products. This campaign will provide a precedent to avoid other oil companies' impunity, that in the same ways cause destruction and death. (Osouka, Martnez, and Salazar 2002)

The international Chevron/Texaco boycott, like the million-strong U.K.-based "StopEsso" boycott of ExxonMobil, connected consumer action with the resistance of oil producing communities in several countries. In 2002, the U.K. polling firm MORI Social Research revealed the following:

The StopEsso campaign is working. In the last year [2001], one quarter of Esso's customers have stopped buying from Esso. One million motorists say they're boycotting Esso because of its stance on global warming . . In July 2002, 5 per cent of car drivers told MORI they were already boycotting the company while 
47 percent claimed they would join the boycott if they were asked to by environmental groups. Greenpeace campaigner Rob Gueterbock said: "The chickens are coming home to roost for the world's number one climate villain. For years Esso has sabotaged every meaningful effort to tackle global warming, including this week's attempt to strike a deal at Johannesburg. But now a million motorists in Britain are punishing Esso at the pumps. If we are going to stop Bush we have to stop Esso. Now everyone can do their bit by joining the growing boycott. (See http://www.stopesso.com/features/feat04.php)

In Nigeria's oil belt, the subsistence way of life was sweet but it was under dire threat from highly destructive oil company production on the cheap. On July 22, 2002, a spokeswoman for occupiers of Chevron/Texaco's Abiteye flow station, Felicia Itsero, 67, spoke to ERA researchers:

We are tired of complaining, even [i.e. and moreover] the Nigerian government and their Chevron have treated us like slaves. Thirty years till now, what do we have to show by Chevron, apart from this big yard and all sorts of machines making noise, what do we have? They have been threatening us that if we make noise, they will stop production and leave our community and we will suffer, as if we have benefited from them. Before the 1970s, when we were here without Chevron, life was natural and sweet, we were happy. When we go to the rivers for fishing or forest for hunting, we used to catch all sorts of fishes and bush animals. Today, the experience is sad. I am suggesting that they should leave our community completely and never come back again. See, in our community we have girls, small girls from Lagos, Warri, Benin City, Enugu, Imo, Osun and other parts of Nigeria here every day and night running after the white men and staff of Chevron, they are doing prostitution, and spreading all sorts of diseases. The story is too long and too sad. When you go (to ERA) tell Chevron that we are no longer slaves, even slaves realize their condition and fight for their freedom. (ERA 2002b)

By 2003, even the IMF recognized that the conditions against which Delta insurgents were protesting and seeking to reverse had reached life-threatening proportions. In a 2003 report, the International Monetary Fund revealed the following:

Between 1970 and 2000, the poverty rate, measured as the share of the population subsisting on less than $\$ 1$ per day, increased from close to 36 percent to just under 70 percent. This translates into an increase in the number of poor from about 19 million in 1970 to a staggering 90 million in $2000 \ldots$ These developments, of course, coincided with the discovery of oil in Nigeria ... Over a 35-year period, Nigeria's cumulative revenues from oil (after deducting the payments to the foreign oil companies) have amounted to about U.S.\$350 billion at 1995 prices. In 1965, when oil revenues per capita were about U.S.\$33, per capita GDP was U.S.\$245. In 2000, when oil revenues were U.S.\$325 per 
capita, per capita GDP remained at the 1965 level. In other words, all the oil revenues-U.S.\$350 billion in total—did not seem to add to the standard of living at all. Worse, however, it could actually have contributed to a decline in the standard of living. (Sala-i-Martin and Subramanian 2003: 4)

Predictably, the IMF recommended a stiffer dose of the poison-still more privatization-to cure "the curse of oil."

The Guardian of May 3, 2003 reported that:

poverty on the Delta is now extreme and communities are desperate for development and work, complaining that none of the billions of dollars earned from oil found under their land has reached them. Many schools have no teachers or books, hospitals and health centres are ill-equipped to deal with malaria and other equa-torial diseases that are rife, and many communities have no electricity. Unemployment is $80 \%$ or more in some places, sanitation is almost non-existent, housing is atrocious, and the death rate amongst children is very high. (Vidal 2003)

A June 2002 report by the Trade and Community Sub-committee of the Nigeria's federal House Petroleum Resources Committee found the Delta's oil communities to be "exploited, misused, abused, polluted, underdeveloped, and almost completely dead; like a cherry fruit sucked and discarded" (Eluemunor and Awom 2002: 1). The "death economy" operations of transnational oil companies were responsible for "the dearth of social amenities in the host communities, the high unemployment, environmental degradation, and even prostitution" (Eluemunor and Awom 2002). Perhaps most damning were the report's findings on "civil unrest." It blamed "some oil companies for encouraging and sponsoring civil unrest in the Niger Delta by engaging in divide and rule tactics by supporting some passive traditional rulers or even communities against radical ones, thus fuelling discord in the region" (p. 1).

In July 2002, the majors made specific promises to the insurgent women. Because Chevron/Texaco and Shell were slow to implement their undertakings, 4,000 Warri women demonstrated on 8 August 2002 at the companies' regional headquarters only to be attacked by police and soldiers. According to protester Alice Youwuren: “we were just singing, we didn't destroy anything. We were peaceful. The police and soldiers misbehaved. Look at me, seven armed men pounced on me and reduced me to nothing. I found myself in a Shell clinic a day after the protest" (Okon and Ola 2002). The United Nations Integrated Regional Information Network (United Nations 2002) reported that Shell police killed at least one woman. Later, Shell "dismissed reports in the local press ... which claimed that a security agent at the scene shot dead an unarmed protestor. 'To the best of our knowledge, the protests at our offices went without any major incident"” (IOD 2002a). 
In an ultimatum published worldwide, the 4,000 women demonstrators gave the Anglo-Dutch giant ten days to pay their hospital bills. Otherwise the women would subject Shell to the curse of nakedness (Adebayo 2002). In much of Africa, women throw off their clothes in an ultimate protest to say "this is where life comes from. I hereby revoke your life." Nakedness by elderly women, in particular, is used in extreme and life-threatening situations. Women wielding the weapon of the exposed vagina could be killed or raped. It is with the knowledge of the act's life and death implications that women enter into such protest. Women who go naked implicitly state that they will get their demands met or die in the process of trying. Many men subjected to this "social execution" believe they will actually die when exposed to such a serious threat. According to one Nigerian source: "in a lot of the rural communities here, the practice of throwing off the wrapper is a common [form of censure, given the] belief among the women folks here that it goes with some magical powers to inflict curses ranging from death to madness on its foes. In the 1980s it was very prevalent among the Gokana people of Ogoni" (International Oil Working Group [hereafter IOWG] 2003b). In 2003, the 1993 Ogoni declaration that Shell is persona non grata in Ogoniland remained in force.

By November 12, 2002, the movement against corporate globalization had expanded dramatically to oppose the impending U.S. military attack on Iraq. Women in California were explicitly inspired by how the Nigerian women who captured Escravos had used the curse of nakedness to shame the men and win their cause. They introduced a new anti-war tactic (Ivan 2002). With their naked bodies they wrote gigantic letters to spell "Peace," photographs of which circulated the globe via the internet and print media to instigate still more nude demonstrators to enact variations such as "No War," "No Bush," "Truth," "Why?," "Paz" and "Paix" (Rosen 2003). In the weeks that followed, naked protests proliferated. Organizers sent photos of their demonstrations to the California women's website (see www.baringwitness.org). Naked anti-war protestors marched in Buenos Aires, Argentina on March 1, 2003. At this point, the Nigeria-inspired anti-oil naked protests had taken place on all seven continents; including blood-chilling Antarctica.

The "Lysistrata Project" emerged in January 2003. Project organizers set up a website that provided several versions of the script of Aristophane's 2,400year-old feminist anti-war drama, Lysistrata. In the play, women from two warring states unite to deny their men sexual and domestic services until the men make peace. The organizers invited anti-war people worldwide to present the play in their own schools, workplaces, and communities on March 3, 2003. Versions of Lysistrata were staged in 1,029 venues in 59 countries, according to the Project's online incident report. Among the theatrical activists were unnamed international journalists who staged a version in Arbil, Iraq, on the eve not of war but of massacre. The organizers described the Lysistrata Project as "the first-ever worldwide theatrical act of dissent" (see www.lysistrataproject.org). In the meantime, 
on February 15, 2003, some 50 million people marched against Bush's attack on Iraq in the largest-ever global anti-war demonstration. Tremendous expectations were raised by these crystallizations, at an international level, of the burgeoning movements against corporate rule and against imperial war (Turner and Brownhill 2001: 806). These expectations were realized in September 2003 when African women were at the forefront of international demonstrators who closed down the World Trade Organization negotiations in Cancun, Mexico.

This international popular power built up through a reciprocal impetus between local and global actions or what Dyer-Witheford (1999) called a "circulation of struggles." Between July 2002 and February 2003, the number of women engaged in naked protests grew from a few thousand in the Niger Delta to several hundred thousand worldwide. The world's first global use of protest theatre contained a three-fold elaboration of the nudity message: first, women were revoking the very lives of men who destroyed subsistence. Second, women were withdrawing all subsistence life support services; especially sex, food, and other housework. Third, the unwaged work of women in sustaining life was juxtaposed (by women and allied men) to the waged work of men engaged in sustaining profits through depredation and war. ${ }^{5}$ Insofar as this challenge was at once global and conscious, it transcended the idea that another world is possible to embody, in however embryonic a form, the actually existing alternative.

The high level of Nigerian resistance to the U.S. war against Iraq forced the corrupt Obasanjo government to stay out of the "coalition of the willing." Obasanjo suffered retaliation in the form of a temporary U.S. withdrawal of some military backing, which shored up his unpopular regime. The opening created by women's takeovers in the oil belt was seized by largely male trade unionists to launch a series of strikes. This extension of insurgency by Nigeria's unwaged majority to the 30 percent of the workforce that earns wages is the focus of part two.

\section{Part 2. February to July 2003 Strikes: "Pirates, Monsters, Miscreants, and Street Urchins"6}

By March 2003, Nigeria was "on the verge of collapse due to strikes" by the Academic Staff Union of Universities, the Department of Petroleum Resources, the Nigerian Union of Railway men, workers of the University College Hospital, Ibadan and the Central Working Committee of Freight Forwarders of Nigeria (Ajaero 2003). Oil workers at TotalFinalElf struck for ten days in March.

In Warri, oil communities lost over 100 people in March 2003 in struggles to take over oil facilities, expel oil contractors, and protest unequal political representation. ${ }^{7}$ Shell and Chevron/Texaco shut in a total of $817,500 \mathrm{~b} / \mathrm{d}$ and by March 25 had evacuated most of their expatriate staff (Nzeshi 2003). As community protests continued, oil workers took over four off-shore oil platforms operated by the U.S. giant Transocean, under contract to the majors. On 
April 16, oil workers onboard the rig MG Hulme staged a wildcat (but unionsupported) strike after Transocean fired five union officers who were organizing against the firm's racist practice of transporting Nigerian workers in boats versus expatriates in helicopters. Transocean flew European workers to the offshore production platforms in some 45 minutes but took over four hours to convey African workers through mangrove swamps where the oil workers were vulnerable to kidnapping and other expressions of oil communities' wrath. On April 19, workers took over Transocean's three other deep-sea oil platforms in solidarity (Oyawiri 2003). Striking workers held the platforms and over 200 foreign and Nigerian oil workers employed by Halliburton, Schlumberger, TotalFinaElf, and Shell. The strike ended on May 2, just as British mercenaries and the Nigerian navy prepared to end the siege with force (Vidal 2003).

An expatriate oil worker who was able to send emails home to his family in Scotland during the siege, reported that the strikers:

flared up and are extremely angry at the thought that the military or armed people are going to come and forcibly remove them from the rig. They threatened violence, in particular to blow up the rig and kill everybody on board. (Carroll and Bowcott 2003)

Some men said they would jump into the sea if necessary, but others said the strikers had "apologized for the threats and indicated that it was all a bluff" (Carroll and Bowcott 2003). NUPENG warned of retaliation if the navy was used to break the strike. A spokesman stated that "if they use force and hurt any of our members, we will hurt the economy" (Carroll and Bowcott 2003). ${ }^{8}$ Expatriate workers subsequently sued Transocean for harm they suffered due to the U.S. firm's failure to treat Nigerian workers in accord with agreed labor standards.

In June, Obasanjo, under pressure from the World Bank, announced a 55 percent increase in the price that Nigerians would have to pay for oil products. After its ultimatum to the government had expired, the National Labor Congress called a general strike for June 30, 2003 to reverse the price increase. On July 2, the third day of the strike, "Ijaw and other pro-Niger Delta activists" announced their intention to "close down all the oil flow stations in the Niger Delta and sack all the oil companies operating in the area [and] target the oil terminals in Forcados and Bonny" (Ebonugwo 2003).

Leaders of the two oil workers' unions responded to the possibility of a community shut-down of oil by backing away from participation in the general strike. ${ }^{9}$ Male dealers in charge of the oil unions were capable of rescinding a strike threat by waged workers. But they were not capable of controlling community occupations of oil facilities. Despite this strategic fault line, by Monday, July 7, day eight of the general strike, waged and unwaged workers in the informal sector had forged sufficient unity to challenge the government's grip on power. The following account of what the Nigerian media called the "day of rage" draws on reports by Ebonugwo (2003) and Ifijeh (2003). 
By July 7, the populace had "fully thrown its weight behind the NLC's (Nigerian Labor Congress) call for civil disobedience, following government's failure to effect a reversal of the new prices after a five-day ultimatum" (Ifijeh 2003). On day eight the general strike was 100 percent effective in Lagos. In a major setback for the government, sections of the police joined the general strike. On July 7, a Lagos police spokesman told the Vanguard that "the OPC was in support of the strike and was taking part in its enforcement"(Ifijeh 2003).

Ebonugwo (2003) reported that:

From as early as 7am, pro-labour protesters, made up of youths, students, artisans, suspected members of the Oodua Peoples' Congress (OPC) led by NLC officials and members of the United Action for Democracy (UAD) broke into the street to protest... The fury knew no bounds with anger visibly written on the faces of the protesting youths... They claimed that they had exhausted food and cash at home after a week of being home for the strike action, denouncing the government for offering to peg petrol price at N35 [U.S.\$.26 per litre]. Nothing short of the old price of N26 [U.S.\$ .20], they said, would be acceptable to them, stating that even the N32 [U.S.\$.24], being negotiated by the NLC with government would not make any significant reduction in prices of goods and transport fares.

In a country in which 70 percent of the population lives on less than U.S.\$1 per day, these fuel price increases marked a major degradation of living standards. The price of one litre of gasoline moved from a fifth to a quarter of daily cash income for almost three-quarters of the population.

In Lagos, "area boys" mounted barricades, made bonfires of used tires, and dumped waste on road sides. They smashed vehicles, robbed drivers who were found on the road, and hijacked motorcycles from delivery men, shouting "don't you know there's a strike today?" (Ebonugwo 2003). Some "hoodlums took advantage of the attendant anti-fuel hike protests to unleash terror and mayhem on hapless commuters and motorists" and "had gone ahead to rape some ladies who dared to venture out in the early hours of the morning" (Ebonugwo 2003) People ran helter skelter to flee the streets. Members of the public reportedly "vowed not to leave their homes again until the NLC called off the strike" (Ebonugwo 2003).

Those police who turned on the public "were beaten back by protesters, who wielded weapons of all sorts. They had asked the police to retreat in their own interest or they would meet them force for force" (Ifijeh 2003).

Women were pivotal in the shutdown because they controlled food transport and sale. "Workers engaged in the informal sector; traders, artisans were the heroes and heroines of the strike ... The informal sector, especially market women played a significant role in the strike" (Vanguard 2003). The highly organized market women and traders kept the markets closed for nine days. Millions 
of urban residents without refrigeration began to run out of food after three days. By Monday, day eight, the government's power was severely compromised: markets remained closed, sections of the police (and army?) were on the side of the general strikers, while those remaining loyal to the government were being trounced by "area boys" and were unable to contain civil disobedience. Activists across the Niger Delta were mobilizing to shut down petroleum flow stations, occupy the oil export terminals and "sack" the oil companies. George Bush was scheduled to arrive in the country four days later, on Friday, July 11.

By day nine of the strike it appeared that power, as C.L.R. James used to say: "was rolling around in the streets" (James and Turner 1971). There were three possible solutions to the crisis. The first was to maintain the status quo of imperialist democracy by acquiescing to the government's and World Bank's fuel price hike. This entailed calling off the general strike. The second was combined action by waged and unwaged workers to shut down the oil industry within the context of the general strike. This resolution would involve the expulsion of the oil companies, the convening of a national sovereignty conference, and the possibility of a revolutionary move towards resource control by national and local communities. ${ }^{10}$ The third option for crisis resolution was yet another military coup.

The real challenge to imperial democracy and oil company control over the economy came from the potentially revolutionary combination of waged and unwaged workers who had the power to expel oil companies from the Niger Delta. To forestall this combination, the Obasanjo regime almost certainly threatened a coup. After Monday's militant protests and faced with the likelihood of a coup, union bureaucrats broke the strike and urged people to return to work. NLC leaders opted for the maintenance of "corporate rule" democracy and quickly settled with Obasanjo on a gasoline price of N34 per litre (a 31 percent hike).

Three observations can be made about the general strike and the sectoral strikes that preceded it. First, in these largely men's strikes, the demands were about terms of labor commodification, not about the defense of subsistence against it. Second, peasants and other informal sector, unwaged people responded positively to the general strike call, but oil workers did not. Third, of the three possible solutions to the political crisis caused by the general strike, the trade union bureaucrats chose bourgeois democracy with a barely veiled military presence immediately behind the throne. In July 2003, sections of the federal military and police began to arrest, manhandle, and usurp elected politicians, including the governor of Anambra State, in what amounted to a "creeping coup" throughout the country and especially in the oil belt.

As the national mobilization of the general strike wound down, the Delta insurgency intensified. Officers of the two oil workers' unions had refused to endorse the general strike. The women of the Delta nullified this betrayal by forcing oil workers off the job. This culmination of a year of growing insurgency is the focus of part three. 


\section{Part 3. Women Assert Community Control in the Delta, July to September 2003}

On July 10, 2003, the day before U.S. President Bush's arrival in Nigeria, women took over many petroleum companies' facilities in the Niger Delta including Amukpe, Sapele West, and Imogu-Rumuekpe. Some 80 unarmed peasant women, ranging in age from 25 to 60, drove oil workers out of the Amukpe flow station, took possession of all vehicles, changed the facility's locks, installed their cooking equipment, made their infants and toddlers comfortable, and began "running shifts" of several dozen women each (IOWG 2003a). The women activists demanded that Shell keep promises made earlier, employ local people, provide domestic amenities including water and electricity, and remove a recently installed chain-link fence that impeded their agricultural product processing. Finally, they said Amukpe would be a "no-go zone for oil companies" if Shell failed to honor past and present demands.

Within days the Delta was substantially under the control of a network of indigenous clan-based organizations. On August 1, 2003, one source reported that "there have been several women's actions here ... the whole place is full of such actions, which are symptomatic of the state of the collapse of the Nigerian state and environmental decay" (IOWG 2003a). The government and oil companies were denied profits from a total of some 1.1 million $\mathrm{b} / \mathrm{d}$ or over a third of Nigeria's estimated overall production capacity of 3.3 million b/d because communities had shut-in $817,500 \mathrm{~b} / \mathrm{d}$ of oil production and were siphoning off another 300,000 b/d (estimates range from 200,000 to 300,000) to sell on their own accounts (Oduniyi, Ugwoke, and Okenwa 2003; Platts 2003). The villagers' actions denied the government an estimated U.S.\$11 million a day and cost the oil companies an estimated minimum of U.S. $\$ 2.5$ million a day in foregone profits alone.

The oil companies demanded military intervention. Civil society organizations, in an open letter to Bush, opposed U.S. troop involvement (ERA 2003). The broad coalition, including Niger Delta Women for Justice, told Bush that "the corporations have been flaring death-dispensing gas into the atmosphere of local communities, mangling fishing waters and farmlands with oil from old and broken pipelines they have refused to maintain and repair, cutting down forests and abolishing fresh water sources. We have seen them march alongside Nigerian soldiers they pay with blood money, into villages and hamlets killing, maiming and raping young men and women whose only crime is that they dared raise their voice to protest the wanton destruction of their lives and sources of livelihood" (ERA 2003).

In July 2003, the Washington D.C.-based Institute for Policy Studies reported that the Pentagon planned "to move between 5,000 and 6,500 troops from bases in Germany to various countries in Africa with the express purpose of protecting U.S. oil interests in Nigeria" (Nuri 2003). Furthermore, "according 
to the Wall Street Journal, U.S. officials claim that a key mission for U.S. forces [in Africa] would be to ensure that Nigeria's oil fields are secure" (Nuri 2003). By September 2003, U.S. troops were in the Delta. The Vanguard reported: "right now we are co-habiting the Niger Delta with the Marines and U.S. Naval patrol boats of different sizes" (Igho 2003).

The Nigerian government and international media rationalized and justified military intervention by reference to "ethnic conflict" in a "failed state." In personal correspondence to the authors, dated September 4, 2003, Chevron/Texaco's Advisor, International Relations, Joseph W. Lorenz wrote: "unfortunately, as a result of ongoing tribal conflict in the region beginning last March and to protect the lives of its employees, CNL [Chevron Nigeria Ltd.] has had to suspend not only its production operations in the delta, but also its community development activities_including Ugborodo New Town" (Lorenz 2003). Oil companies were notorious for engineering conflict. As Nimmo Bassey, director of Nigeria's ERA, asked: "how can peace find a foothold on these shores when communities that have lived at peace for centuries are engineered to live in suspicion of each other and in conflict with one another while others plunder their resources?" (Bassey 2002). By fomenting division, oil companies fulfilled Brzezinski's (1997) imperative to "keep the barbarians from coming together" (p. 40). The Economist, in a May 2003 review of Paul Collier's World Bank report Breaking the Conflict Trap: Civil War and Development Policy (2003), endorsed Collier's resuscitation of the old imperialist rationale that military "peacekeeping" was the only route to "stability" and hence to poverty alleviation. Washington had planned the West African military incursion, apparently since at least 2000, in tandem with its attack on Iraq. Bush's State Department head of policy planning, Richard Haass argued back in 2000 that the United States, the number one superpower, should multiply its military interventions in order to enhance its global strategic assets: "imperial understretch, not overstretch appears to be the greater danger of the two" (Haass 2000). ${ }^{11}$ In September 2003, Monbiot observed: "now that the U.S. controls the shipping lanes of the Middle East and the oilfields of central Asia and West Africa, it is in a position, if it so chooses, to turn off the taps to China, its great economic rival, which is entirely dependent on external sources of oil" (Monbiot 2003: 11).

But in Nigeria, as in Iraq, it is unlikely that the United States can succeed in actually controlling the oil industry through force of arms or legal maneuvers such as Presidential Directive 13303, which gives U.S. oil companies immunity from prosecution for their actions in Iraq (Girion 2003; Kerr 2003). The Delta has a long history of success in repelling invasion by sea. Allusions to a contemporary chapter were made by the chairman of Burutu local government area of Delta state, Asupa Forteta, who on July 18 decried the "high level of brigandage and turbulence being witnessed in the riverine communities and waterways." He sought to stamp out "anti-social vices such as piracy, hostage taking, oil pipeline vandalisation, and so on." The military advantage enjoyed 
by residents indigenous to the Delta was underlined: "those behind these dastardly acts are people that you and I know; strangers cannot effectively operate in our terrains because of its peculiarity" (Delta State Government 2003). Half-hidden in chairman Forteta's declamation was the insight that only members of oil communities could defend the Delta or carry out illegal bunkering because only they could "effectively operate in our terrains."

After activists established control over much of the western Delta's oil production infrastructure by March 2003, did they secure and sell crude on the international market? Are villagers and ex-oil workers not only shutting down the industry, but also restarting it on their own account by marketing crude and products? These questions are sharpened by press reports in 2003 of armed Delta youth overcoming the Coast Guard and "rescuing" an impounded illegal bunkering vessel. Does this confrontation foreshadow, in part, the future content of the struggle for resource control? Are peasants going beyond the sacking of oil companies to start up the lifting and sale of crude on a new basis? Are they defending the process by force of arms? The government's armed forces lost most confrontations in the byzantine mangrove swamps of the Delta's riverine zones. The combined forces of the oil companies, federal and state governments, and all their law enforcement agencies had not, by late 2003, suppressed the Delta militants, in part because "strangers cannot effectively operate in our terrains" (Delta State Government 2003). Many militants were said to be armed by "illegal oil traders" or those positioned to buy guns with proceeds from that trade. Is the future of twenty-first century subsistence on the Delta enclosed in the potential for direct producer-consumer deals in oil?

In early September 2003, Delta activists held the oil installations and continued to shut-in some 40 percent of oil production. Their capacities to withstand military attacks have to do with the high level of community solidarity, explicit direct involvement by women who control food supplies and trade, and the extremely complex and inaccessible nature of the mangrove swamp terrain. The "resource control" revolutionaries are well armed. Buyers abound for parallel market crude. Solidarity with Delta commoners goes deep, reaching back to pro-Biafra campaigns in the 1960s, anti-apartheid cooperation in the 1970s, networks to stop oil to the racist regime in South Africa in the 1980s, "boycott Shell" mobilizations to support the Ogoni struggle in the 1990s and in the 2000s, and the groundswell of anti-war nude militancy by women in and after the seizure of Chevron/Texaco's Escravos oil terminal in 2002.

Beyond international solidarity is the deepening of relations fundamental to global alternatives to corporate rule. Direct producer-consumer oil deals are central to these alternatives. Nigerian insurgents may already be fashioning direct deals. Since 1985, Nigerians have organized oil barter or "countertrades." Supplies of Nigerian crude would make possible popular, ecologically sound citizens' control of refineries in Trinidad and Tobago, in 
South Africa, in Cuba, and elsewhere. These visions of the future inform the strategizing of commons environmentalists and "resource control" activists.

Chevron/Texaco, Shell, Exxon/Mobil and the other oil companies in Nigeria may visit the Delta peoples with terrible military carnage. International vigilance and readiness to hold the corporations accountable are deterrents. The majors seek direct control over Nigerian, West African, Middle Eastern, Asian, and Latin American petroleum reserves. Instability in oil producing countries, and shutdown petroleum facilities are not necessarily shunned by the majors. They can be turned to a profit. ${ }^{12}$

\section{Conclusion: "Stand up now"}

I call upon the Ogoni people, the peoples of the Niger Delta, and the oppressed minorities of Nigeria to stand up now and fight fearlessly and peacefully for their rights. History is on their side, God is on their side. For the Holy Quran says in Sura 42, verse 41: 'All those who fight when oppressed incur no guilt, but Allah shall punish the oppressor'. Come the day.

-Ken Saro-Wiwa (1995), Pre-Conviction Statement prior to his hanging by the Abacha military regime on November 10, 1995

This conclusion considers first, the roots of insurgents' power in subsistence and corporate organization, and second, direct producer-consumer deals.

In 2003, Epstein argued that it is only by "draw[ing] out the connections between production and consumption under capitalism" that the global anti-war movement can gain "staying power, the capacity for its different elements to coalesce, and a meaningful political praxis" (Epstein 2003: 116). This study has drawn out those global connections between production and consumption as they emerged through conscious praxis at the community and world levels in the period from July 2002 to September 2003. It has treated the genesis, successes, and possible futures of these global gendered class alliances by relating them to the defense and re-invention of the commons and the subsistence political economy, north and south (Bennholdt-Thomsen and Mies 1999: 144).

The central focus in this concluding assessment is on the sources of insurgent power. Power arose from defending the social relations of subsistence and attacking the social relations of commodification; the unwaged were, and are, integrated inextricably into both. Women and their allies were able to achieve a remarkable degree of success by commanding and exercising power grounded in their own life-centered political economy and in the enclosing oildeath economy. The two foundations of insurgent peasant power were subsistence itself and the organization bequeathed by the transnational oil corporations. Both groundings were at once national and international.

First, the unwaged, peasants, indigenous people, and women were firmly ensconced on the commons and enjoined by communal social relations 
(Midnight Notes Collective 1990: 1-9). ${ }^{13}$ These "civil commons" provided the means through which to satisfy most life needs. These are the same life grounds and commons that capital sought to enclose, commodify, and destroy. The commons, then, were both a site of struggle and a crucial source of the power for Escravos and all Niger Delta communities in their war against the oil transnationals. Central to the continued existence of the commons in the Niger Delta are the village, trade, and clan-based organizations that prosecuted the insurgency. Over the past decade, through processes of direct democracy, each "nationality" formulated declarations that contained demands and programs. A fundamental universal demand is "resource control." More recently, coalitions of these clan-based organizations have been formed and are calling for a national sovereignty conference to remake the Nigerian political economy. Prominent among the many cross-cutting solidarity networks was Chicoco, which brought together some 27 ethnic groups of small farming and fishing peoples. Crucial for women's unified and sustained action was the pan-Delta and international Niger Delta Women for Justice. ${ }^{14}$ Autonomous village organizations, linked to each other through regional solidarity networks, coordinated pan-Delta defense against Nigerian and U.S. military counterinsurgency and took over much of the governance of their own communities.

The subsistence political economy supported the unwaged majority and the waged minority. While insurgents frequently charged oil companies with holding communities hostage, in reality many peasants were food self-sufficient. As all were reminded during the general strike, women controlled strategic urban food sources. Most low-waged workers relied on African women engaged in subsistence production and trade for their needs. At the same time, oil companies ravaged the environment and made it increasingly untenable for anyone or anything to survive in the vicinity of oil wells, pipelines, flares, and other production and export facilities. These facts go a long way toward explaining why women were at the forefront of Nigeria's 2002-3 oil wars. They held their ground to defend subsistence against the most powerful corporations in the world. They did so peacefully; armed with actual, considerable power to give and deny life. This moral high ground gave women warriors the capacity to visit public relations catastrophes on oil majors which, in 2003, were struggling to annex Iraq's 250 billion barrels of oil behind the thin veil drawn by their seconded personnel in the White House. In the highly-developed subsistence political economy of Nigeria, the threat of women's naked protests had a Hydralike power to force men to stop and flee in fear (Linebaugh and Rediker 2000: 327-54). It was a power that eroded the surety of the male deal between Nigerian men and the oil "corporate male gang" (McMurtry 2001). When women made international connections and took naked protests to the global stage, their aim was precisely to break down the bonds of the global male deals that were driving Bush's neoconservative Imperial America toward new oil wars. 
This brings us to the second source of the power of the emergent global gendered class alliances against the oil-war machine: the corporations themselves. Insurgents in Nigeria's oil war built links with other national and international actors in three integrated arenas: the parallel market, boycotts, and the coordinated assertion of community control over petroleum resources. As oil companies consolidated and militarized their global control over oil resources, they bound together, more closely, the interests, capacities, and experiences of people in all parts of the world. Shell united insurgents in four strategic countries (the United States, Nigeria, South Africa, and Indonesia) to produce a damning document called The Other Shell Report $2002 .{ }^{15}$ U.S. military adventurism in Iraq, Venezuela, Indonesia, and Nigeria has produced sharper and deeper national opposition to foreign petroleum capital and its drive to privatize especially the upstream industry. Second, it has forged tighter international unity among the resistance to U.S. military interference in the four countries. Both effects have multiplied possibilities for coordination against imperial oil and for popular, international control over a restructured oil industry.

Oil companies' environmental racism impelled communities to enforce resource control. They organized joint producer-consumer actions against oil companies and oil wars. These began with Nigerian women's 2002 Chevron/Texaco takeovers and continued with international boycotts from September 2002, women's naked protests in California in November 2002 (and worldwide thereafter), and the 50 million strong global anti-war demonstration of February 15, 2003. These global actions were extended by countless national actions worldwide, including Nigeria where people forged a national producerconsumer alliance against big oil during the general strike of June to July 2003. Throughout the period, the demands of the Niger Delta women continued to present the most far-reaching challenges to corporate oil power. ${ }^{16}$ They used nakedness and direct occupation of oil facilities to break the male deal. They explicitly demanded that the oil companies "should leave our community completely and never come back again" (ERA 2002b). By September 2003, the attenuation of corporate rule worldwide was heralded by the end of multilaterial "trade liberalization" negotiations through the WTO. The unity which brought about the collapse at Cancun is a basis for global debt repudiation, the expansion of myriad solidarities, and the negotiation of direct, fair, self-valued trade.

Direct deals are alternatives to market control by the majors. In Nigeria, were barrels shut in and then sold on the international and national markets? Was the buoyancy of the parallel market in Nigerian oil a central motivation for U.S. military intervention? ${ }^{17}$

The crucial gendered and ethnicized class unity demonstrated in producer-consumer joint actions is a precondition for going beyond oil production shutdowns. If Nigerian oil workers, indigenous communities, and other democratic organizations in the future move beyond shutdowns to running the 
oil industry on their own, the widely articulated goals of reparations for the environmental debt owed Nigeria, pollution cleanup and wise use of petroleum wealth could be realized. A kind of reparation would be won to the extent that oil workers and indigenous organizations would be able to sell or barter oil directly. Direct deals would enable a Nigerian "sovereign national convention" to use the proceeds to support life, and stop the current practice of revenue theft and the use of foreign exchange from oil sales to service ever-increasing levels of International Monetary Fund, World Bank, and Paris Club debt.

In 2001, the noted oil economist Michael Tanzer encouraged direct deals via multi-state oil barter: "by developing a multilateral barter exchange system for Third World commodities, such a strategy could secure reliable revenues for the oil-exporting countries, while providing the oil-importing countries with a steady flow of oil, and with export outlets at fair prices for their own commodities" (Tanzer 2001: 24). In 2002, feminist economist Ellie Perkins (2002) identified typical features of such direct deals in which value is set by discourse between autonomous "resource controlling" parties. ${ }^{18}$

This analysis of Nigerian women's shutdown of major oil companies from 2002 to 2003 and the alliances they forged at home and abroad has explained why women are at war by arguing that they are in the process of defending subsistence. It has accounted for the sweep of the insurgency's growth by reference to the force of oil companies as agencies for the organization, unity, and discipline of those caught in corporate nets. Women worldwide, by asserting life against the corporate death economy, are impelling the movements against neo-imperial war for corporate rule to champion a subsistence life economy alternative. The future of the oil component of this new set of social relations lies in the elaboration of direct deals between producers and consumers who have a track record of coordination in wresting resource control from oil corporations.

\section{NOTES}

1. In 1999 the major oil companies active in Nigeria and their share of crude oil production were Shell, 40 percent; Mobil (now Exxon/Mobil), 25 percent; Gulf (now Chevron/Texaco), 21 percent, and Agip (now TotalFinaElf), 12 percent. Two percent of production was shared by Ashland (of the United States), Deminex (Germany), Pan Ocean (Switzerland), British Gas, Sun Oil (United States), Conoco (United States), Statoil (Norway), Conoil (Nigeria), and Dubril Oil (Nigeria). The Nigerian National Petroleum Corporation (NNPC) had a 55 to 60 percent joint venture interest in the majors' operations. The United States took about 40 percent of Nigeria's exports. The remainder was exported to Spain, South Korea, India, France, Japan, China, Taiwan, the Philippines, and Thailand (Frynas 2000: 16, 246-7; Okonta and Douglas 2001: $54)$. 
2. An exception to the silencing of women and, more broadly, the analysis of Niger Delta gender relations is Sokari Ekine's (2001) oral history-based account of women's experiences with the oil companies and their military defenders.

3. This is a chant sung by women during their occupation of Chevron/Texaco's Abiteye flow station in July 2002 (cited in Okon and Ola 2002). It echoes Fela Anikulapo-Kuti's "No Agreement," originally released in 1977 by Fela Anikulapo-Kuti and The Africa 70.

4. In September 2002, in Rio de Janeiro, David O'Reilly, Chevron/Texaco's chairman and chief executive officer, addressed oil industry executives at the Seventeenth World Petroleum Congress, on the matter of Nigerian village women's seven occupations of oil facilities. In contrast to Queen Uwara's testimony that "Chevron brought soldiers and police to threaten us when we were at Chevron yard" (ERA 2002a), O'Reilly claimed that the oil company's Nigerian representatives had handled the situation "with great sensitivity" and that he was "proud of their efforts" to reach an understanding with the women (IOD 2002c). In a personal communication to the authors, dated September 4, 2003, Chevron/Texaco's Advisor, International Relations, Joseph Lorenz repeated the refrain about pride: "Chevron/Texaco is proud of its reputation as a concerned and caring neighbor and believe our actions-which quietly occur each day in the Niger Delta-exemplify this commitment."

5. Contrast the nudity of anti-oil, anti-war activists with the titillating near-nudity of contestants in the Miss World contest. In November 2002, Miss World contestants gathered in Nigeria and prepared to strut down the cat-walk with low-cut or see-through evening gowns to be judged on their physical appearance. A Nigerian woman fashion reporter wrote an article about the beauty queens which some Muslims read as blasphemy. Riots erupted in the streets in Northern Nigeria and over 200 people were killed. Women's nakedness in the context of protests against big oil and war was concerned with birth, regeneration, the womanly source of life and subsistence, as well as the power to take life that has been given. In contrast, the beauty queens' hyper-sexualized bodies showed no signs of having given birth. These bodies were shaped by the multi-billion dollar markets in plastic surgery, cosmetics, diet products, children's Barbie dolls, fashion, pornography, and violent "entertainment." Just as the potency of naked protest derived from women's importance to the subsistence production of human life, the power of the near-nakedness of beauty contestants was rooted in its centrality to the commodified pursuit of profits for major corporations.

6. The multitudes who executed the Nigerian insurgency constitute an alliance across gender, age, and ethnicity among those who are exploited and 
dispossessed, whether waged or unwaged. "Pirates, monsters, miscreants, and street urchins" are descriptors used in Nigerian press accounts of the 2002 to 2003 strikes and insurgency. "Pirates" and "miscreants" refer to those who sold oil products on the parallel market and who stopped oil vessels on the high seas and the Delta creeks to demand payment for passage. "Hydra-headed monster" was used in a discussion of conflict in oil communities to describe three ethnic groups in the Delta: Ijaw, Itsikeri, and Urhobo (Nzeshi 2003). The writer blamed the conflict on the ethnic groups rather than on the destruction and enclosure of the commons; the competition for jobs, revenues, and resources; and the divisive tactics of the oil companies. On the other hand, Nnimmo Bassey, Executive Director of ERA, described Shell's giant new Floating Storage Production and Off-loading (FPSO) vessel as "a monster rearing its head" (Kpor 2002). "Street urchins" were part of the multitudes who participated in the general strike from June 30 to July 8. Nnanna (2003) stated that the leader of the Nigerian Labor Congress, Oshiomhole, should:

take adequate judicial note of those very important Nigerians, whom the police often foolishly describe as 'street urchins.' Those are the people that give industrial struggles such as we have just passed through their potent striking power. They are the people who get shot at for coming out to express the feelings of the people, even if sometimes a little bit exuberantly. Those 'street urchins' are Nigerian youths united irrespective of tribe, religion, region or party affiliation, against obnoxious official policy. The police would not grade them as 'street urchins' if their demonstration was in favour of the government of the day for any reason. They would then become "patriotic Nigerian youths.

The multitudes also included market women, traders, artisans, other informal sector workers, religious leaders, bank workers, concerned professionals, trade unionists, "area boys" or unemployed urban youth, teachers, university lecturers, students, prostitutes, activists of all stripes, governors Bola Tinubu of Lagos State, Ibrahim Shekarau of Kano and Bafarawa of Sokoto State, unemployed people, villagers, and subsistence farmers and fishers.

7. Four months later, on July 2, 2003, three oil workers died in a fire outbreak ignited by an explosion on a contractor's drilling rig (IOD 2003a). In addition, the Nigerian press reported hundreds of people killed in the Delta in the July to August 2003 struggles. Organizations of Ijaw people on two occasions published protests in the popular press against alleged military counterinsurgency pogroms.

8. In a simultaneous but possibly separate struggle concerning the "Sea Eagle" FSPO (floating production, storage and offloading vessel), on April 28 Shell 
took out full-page advertisements in Nigerian newspapers saying that it "had been warned that criminal elements were threatening to explode a mammoth oil tanker that Shell had converted into a mobile, all-purpose, floating oil production platform." The ad warned that "the scale of economic, human and environmental carnage that a blow-out on the FPSO can result in is unimaginable ... Information reaching us reveals that anytime from now, the vessel could be boarded by force of arms and set on fire" (BBC News 2003).

9. On July 3, day four of the strike, the oil workers' junior staff union NUPENG had begun removing staff from posts. But NUPENG called off the strike action on July 4, day five of the national action. Then on July 5, day six of the strike, the Trade Union Congress called off its strike action. This immediately prompted the senior oil staff union, PENGASSAN, to cancel its participation in the general strike, which it had intended to begin on Sunday, July 6 (IOD 2003b).

10. Nnanna (2003) characterized the strike as "a great historic struggle of the Nigerian people."

11. By 2002, Richard Haass was arguing that a state that was unable to control terrorism at home had lost "the normal advantages of sovereignty, including the right to be left alone inside own territory. Other governments, including the U.S., gain the right to intervene. In the case of terrorism this can even lead to a right of preventative, or preemptory, self-defense" (Haass, Richard, quoted in Michael Hirsh 2003: 251).

12. The oil companies are in the business of making profits, of securing a return higher than the Fortune 500 industrials' average rate of profit (Bichler and Nitzan 2002; 2003; Nitzan and Bichler 2003). Violence, military attacks, and instability drive up prices even if they do not impose actual shortages of crude on the world market. Higher prices mean higher profits. The majors' seek to control oil reserves in order to control how much oil is on the market, the terms of its sale, who buys it and at what price. Nitzan and Bichler have demonstrated that when major oil companies' profits fall below the average, war is fomented and profits recover. Their analysis argues that the oil companies want, and possibly promote, strife in producing societies. This is especially the case in the 2000s when, they argue, the majors are pursuing an accumulation strategy based on stagflation (stagnation of the economy, inflation in prices). Higher oil product prices can only be imposed on the consumer under crisis conditions (war on terrorism, suspension of civil liberties). This accumulation strategy is a corporate weapon against deflation and the implosion of the capitalist system. It is in this international strategic framework that the struggles in Nigeria's oil belt can best be analyzed and understood. 
13. In their issue of Midnight Notes entitled The New Enclosures, the Midnight Notes Collective presented what is possibly the most important theoretical analysis of the emerging global revolutionary movement, which, 13 years later, caused the WTO collapse at Cancun. In the introduction to the issue, the collective states:

the very extremities of the debt crisis and the need to organize reproduction outside of the money relation has often forced workers to develop their autonomy by imposing the task of creating a whole system of production and reproduction outside of the standard operating procedures of capitalist society. . . For example, an important aspect of the [June 1987] strike against International Paper in Jay, Maine lies in the strikers' support for an environmental ordinance that literally said to IP: if you demand total control of the production process inside the plant, we demand total control of the reproduction process outside the plant ... if one generalized the Jay workers' tactic into a struggle that denied capital the possibility of enclosing and selectively destroying the natural commons gratis, a truly revolutionary crisis would emerge. Such a shift in the direction of the ecology movement would be one part of a larger process which would transform the New Enclosures into a definitive occasion of proletarian unification and capitalist catastrophe. In practice this means the creation of individuals and organizations that can both think and act globally and locally which is exactly what the struggles around the New Enclosures do. The root of this result is actualized in the struggles against the New Enclosures that simultaneously re-appropriate and hold places from capital while opening spaces for proletarian movement. (Midnight Notes Collective 1990: 6, 8, 9)

14. In August 2000, twelve Niger Delta women met in Banjul, the Gambia, and resolved that:

a) Oil exploration, production and all other activities be suspended with immediate effect until amenities such as pipe borne water, electricity, safe water transportation systems, functional health centers, scholarship schemes, and schools are provided in the Niger Delta;

b) All laws inimical to the development of the Niger Delta people be repealed, including a total rejection of the 1999 constitution;

c) All victims of oil spillages and fire disasters be compensated and treated;

d) All qualified youths in the Niger Delta be gainfully employed by the government and multinationals and those summarily dismissed be reinstated;

e) The percentage of interest payable on micro credit loans should be determined by participating women;

f) The multinationals and government desist from making allegations of sabotage without proper investigations of any spill and stop the indiscriminate employment of youths of the Niger Delta for cleaning up exercises without appropriate protection, as a result of which their life spans are reduced drastically; 
g) The Niger Delta women be empowered economically, in order that they may claim their right to political empowerment;

h) A law be enacted making it mandatory for oil companies to take responsibility for the welfare of any child and mother of such child born out of company's staff's promiscuous activities;

i) Forthwith, any act that will further devastate the environment (our aquatic and ecological environment) be stopped immediately and all devastated environments be cleaned up;

j) Henceforth, all oil companies and sub-contractors adhere to all regulations and laws that apply to global environment standards and Environmental Impact Assessment reports must be made public.

k) We be represented in all decision-making processes that affect us in the Niger Delta;

1) We totally support all the declarations of the ethnic nationalities of the Niger Delta for resource control, self determination, and true Federalism;

m) All those unjustly detained should be released with immediate effect; and

n) The only solution to peace in the Niger Delta is justice. (Niger Delta Women for Justice 2000)

15. The Other Shell Report demanded that Shell "send skilled and experienced international officials to meet with representatives at the sites where people living nearest to Shell are experiencing difficulties, and resolve these [environmental and health] problems." The report called for Shell to "support national and international laws that allow affected communities to hold companies like Shell accountable for their negative impacts" (Other Shell Report 2003: 5).

16. On the one hand, Nigerian women and their allies, by expelling the majors from the Delta, cut out of the world market some $800,000 \mathrm{~b} / \mathrm{d}$. They thereby raised prices and the overall take of the majors and OPEC governments. In the first quarter of 2003, Shell and Chevron/Texaco scored their highest profits ever: "Exxon, the world's largest oil group, reported the biggest quarterly corporate profits in history at $\$ 7 \mathrm{bn}$..." (Gow 2003). Michael Shames, executive director of Utility Consumers Action Network, a watchdog group in San Diego, California, said Chevron/Texaco's 2003 first quarter doubling of profits is "[d]isgusting. It really is ... It confirms my thesis that they weren't [merely] passing on higher costs of oil to consumers; they were gouging customers" (Kopytoff 2003). Bichler and Nitzan (2003) and Nitzan and Bichler (2003) argue that the oil majors made war to increase their profits which had fallen, between 1980 and 2000, from 19 to three percent of the world corporate total. Price hikes by the weapondollarpetrodollar coalition were supported by non-oil corporations. These were keen to impose stagflation and dispel the nightmare of deflation by forcing on "terrorized" consumers the oil cost hikes embodied in their commodities.

On the other hand, on a national basis, insurgents forced net losses on Shell, 
Chevron/Texaco, the other international subsidiaries, and the Nigerian government. The Nigerian government losses from the shut-in of March 1 (assuming that it continued to the end of 2003) of some $800,000 \mathrm{~b} / \mathrm{d}$ and the diversion of some $200,000 \mathrm{~b} / \mathrm{d}$ onto the parallel market were an estimated minimum of U.S. $\$ 3.366$ billion (assuming an average crude oil price of U.S. $\$ 25 / \mathrm{b}$ minus a $\$ 3 / \mathrm{b}$ production cost). Oil companies operating in Nigeria lost U.S.\$765 million (assuming U.S.\$22/b for crude and a U.S.\$5/b refining margin). But because production shut-ins in Nigeria, Iraq, and Venezuela created the perception of supply shortfalls, the world crude oil price rose in 2003. Assuming a U.S.\$30/b world price for Nigerian crude, government income from its 50 percent share of a 2 million b/d production for the period from March 1 to December 31, 2003 totaled approximately U.S. $\$ 18.176$ billion. On the same assumptions and with a U.S. $\$ 5 / b$ refinery margin, the oil companies secured a net income on their one million b/d of U.S.\$3.06 billion. On the basis of these estimates, the Niger Delta oilfield takeovers (if they persisted throughout the last 10 months of 2003) reduced government oil income (including windfalls from higher prices) by 19 percent. The takeovers reduced the oil companies' income by 25 percent.

17. After Venezuela and Cuba struck barter deals whereby Cuba got oil in exchange for medical services and generic drug manufacturing processes, the United States objected. Iraq's barter deal with India which secured the oil exporter grain and bought India crude was met in July 2002 with U.S. and British opposition through the UN oil sales program and in 2003 through U.S. military attack. Nigerian citizen-negotiated direct deals were under attack by the U.S. oil companies, the Nigerian government, and by September 2003, by the U.S. military. The U.S. regime, on behalf of the oil majors, has everywhere opposed oil barter with all its tremendous subsistence-promoting potential. But Imperial America has even more vigorously opposed public control of oil and gas exploration, production, and reserves through state-owned corporations.

18. According to Perkins:

The characteristics of discourse-based valuation are as follows: (1) It brings together all constituencies concerned with the outcome of a particular political decision to consider collectively the options and tradeoffs involved. (2) It requires a considered and concerted effort to include, respect, and give voice to ALL constituencies affected. Near the beginning of the process, participants take time to consider who is not present that should be present, and how best to include those missing concerns.

(3) Government officials and agencies are committed to implement and act upon the decisions and outcomes of the discourse process. (4) It generally begins, and is most useful, at the local level. The particular form 
the process takes is determined by the participants. (5) It starts from local needs and priorities. (6) It explicitly acknowledges that valuation in money terms is problematic for many important goods and services, and emphasized the issues of commensuration, compensation, and trade-offs among marketed and unmarketed things. (Perkins 2002: 16-17)

\section{REFERENCES}

ABIOLA, Adebayo Coker 2002. "Chevron Ignores Demand of Women for Employment and Clean Environment.” ERA Field Report \#103, July 14.

ADEBAYO, Sola 2002. "N-Delta Women Give Shell 10-day Ultimatum on Demands." Women of Nigeria International (WONI) and Women's International League for Peace and Freedom (WILPF), November 14.

AHIUMA-YOUNG, Victor 2003. "Why We Suspended Fuel Price Hike Strike-NLC." Vanguard (Lagos), July 28.

AJAERO, Chris 2003. "Grinding on the Wheels of Strikes.” Newswatch (Lagos), March 8.

BASSEY, Nimmo 2002. "What Peace in the World Today?" Conference marking the International Day of Peace, Benin City, Nigeria, September 21.

BBC NEWS 2003. "Shell Advertises Nigerian Woes.” April 28.

BENJAMIN, Craig S. and Terisa E. Turner 1992. "Counterplanning from the Commons: Labour, Capital and the 'New Social Movements." Labour, Capital and Society 25(2): 218-48.

BENNHOLDT-THOMSEN, Veronika and Maria Mies 1999. The Subsistence Perspective: Beyond the Globalised Economy. London: Zed Books.

BICHLER, Shimshon and Jonathan Nitzan 2002. The Global Political Economy of Israel. London: Pluto.

BICHLER, Shimshon and Jonathan Nitzan 2003. "Dominant Capital and the New Wars." Paper presented at a Conference on Global Regulation, Centre for Global Political Economy at the University of Sussex, May 29-31. Forthcoming in Journal of World Systems Research. Available at (http://www.bnarchives.net)

BROWNHILL, Leigh S. and Terisa E. Turner 2004. "Feminism in the Mau Mau Resurgence." Journal of Asian and African Studies, 39(1/2).

BRZEZINSKI, Zbigniew 1997. The Grand Chessboard: American Primacy and its Geostrategic Imperatives. New York: Basic Books.

CARROLL, Rory and Owen Bowcott 2003. "Nigeria Pits Navy against Oil Rig Hostage Takers." The Guardian, May 1.

CHEVRON/TEXACO 2003. Personal Communication, September 4.

DELTA STATE GOVERNMENT 2003. "Burutu LG Boss Launches Anti-Piracy Team.” Delta State Government News, July 18.

DYER-WITHEFORD, Nick 1999. Cyber-Marx: Cycles and Circuits of Struggle in HighTechnology Capitalism. Urbana and Chicago: University of Illinois Press.

EBONUGWO, Mike 2003. “Bad Price for Fuel Price Hike.” Vanguard (Lagos), July 2. 
EKINE, Sokari 2001. Blood Sorrow and Oil: Testimonies of Violence from Women of the Niger Delta. Oxford: Centre for Democracy and Development.

ELUEMUNOR, Tony and Uchenna Awom 2002. "Oil Firms Indicted over Huge Joint Venture Fraud." Daily Independent, Nigeria, June 24-30, p. 1.

ENVIRONMENTAL RIGHTS ACTION (ERA) 2002a. "Confronting Chevron: Women Stare down the Barrel.” Environmental Testimonies No. 28, July 13.

ENVIRONMENTAL RIGHTS ACTION (ERA) 2002b. "Protesting Women Continue Occupation of Chevron Flow-stations.” ERA, July 22.

ENVIRONMENTAL RIGHTS ACTION (ERA) 2003. "Press Statement: Groups Oppose U.S. Troops Deployment to Niger Delta.” ERA, July 11.

EPSTEIN, Barbara 2003. "Notes on the Antiwar Movement." Monthly Review 55(3): 109-16.

FRYNAS, G. 2000. Oil in Nigeria: Conflict and Litigation between Oil Companies and Village Communities. London: Lit Verlag.

GIRION, Lisa 2003. "Immunity for Iraqi Oil Dealings Raises Alarm.” The Los Angeles Times, August 7.

GOW, David 2003. "Shell Doubles its Earnings." The Guardian, May 3.

HAASS, Richard N. 2000. "What to Do with American Primacy."

HIRSH, Michael 2003. At War with Ourselves: Why America is Squandering its Chance to Build a Better World. New York: Oxford University Press.

IFIJEH, Godwin 2003. "When Fuel Price Hike Protest Went Wild." This Day (Lagos), July 10.

IGHO, Eferovo 2003. "Niger Delta: Death Versus Development," Vanguard (Lagos), September 4.

INTERNATIONAL OIL DAILY 2002a. "Shell Denies Killing Protester." International Oil Daily, August 14.

INTERNATIONAL OIL DAILY 2002b. "Nigerian Women Seize Platform." International Oil Daily, August 19.

INTERNATIONAL OIL DAILY 2002c. "Strong Partnerships Are Key for Success of Big Oil, Says Chevron's O'Reilly.” International Oil Daily, September 5.

INTERNATIONAL OIL DAILY 2002d. "Protests Disrupt Warri Output.” International Oil Daily, September 23.

INTERNATIONAL OIL DAILY 2003a. "Three Die in Nigeria Fire.” International Oil Daily, July 3.

INTERNATIONAL OIL DAILY 2003b. "Nigerian Oil Operations Continue, as Unions Consider Proposal.” International Oil Daily, July 8.

INTERNATIONAL OIL WORKING GROUP 2003a. Interview No. 1 with Nigerian source, August 1.

INTERNATIONAL OIL WORKING GROUP 2003b. Interview No. 2 with Nigerian source, August 2.

IVAN, Gale 2002. "West Marin Women Strip for Peace," Point Reyes Light, (Marin County California), 14 November.

JAMES, C.L.R. and Terisa E. Turner 1971. Personal communication. 
KERR, Stephen James 2003. “The End?” ZNet, August 6.

KOPYTOFF, Verne 2003. "ChevronTexaco on a Roll: Oil Company Benefits from High Pump Prices.” San Francisco Chronicle, May 3.

KPOR, Cudjoe 2002. "Why Era Opposes Shell's Offshore FPSO Vessel." Daily Independent (Lagos), June 24-30, p. B2.

LINEBAUGH, Peter and Marcus Rediker 2000. The Many-Headed Hydra: Sailors, Slaves, Commoners and the Hidden History of the Revolutionary Atlantic. Boston: Beacon.

LORENZ, Joseph W. 2003. Chevron/Texaco Advisor, International Relations. Letter to the authors, September 4.

MARX, Karl [1887] 1967. Capital, Vol. I. New York: International Publishers.

MCMURTRY, John 2001. "The Life-Ground, the Civil Commons and the Corporate Male Gang." In Gender, Feminism and the Civil Commons, Special Issue of the Canadian Journal of Development Studies Vol. XXII, edited by Terisa E. Turner and Leigh S. Brownhill.

MCMURTRY, John 2002. Value Wars: The Global Market Versus the Life Economy. London: Pluto.

MIDNIGHT NOTES COLLECTIVE 1990. "Introduction to the New Enclosures." In The New Enclosures: Midnight Notes, Fall 1990.

MONBIOT, George 2003. "Beware the Bluewash." Guardian Weekly, September 4-10, p. 11.

NNANNA, Ochereome 2003. “A Struggle, Not Just a Strike.” Vanguard (Lagos), July 10.

NIGER DELTA WOMEN FOR JUSTICE 2000. "Communique and Fourteen Resolutions Issued by the Consultative Meeting of Niger Delta Women." Banjul, the Gambia, August.

NITZAN, Jonathan, and Shimshon Bichler 2003. "It's All About Oil." News From Within XIX(1)January 8-11.

NORE, Petter and Terisa Turner, eds 1980. Oil and Class Struggle. London: Zed Books.

NURI, Joia Jefferson 2003. "US Troops Move to Africa to Protect Oil Interests." Institute for Policy Studies, July 9.

NZESHI, Onwuka 2003. “Okerenkoko: Battle On the Jungle Island.” This Day (Lagos), March 25.

ODUNIYI, Mike, Francis Ugwoke, and Lillian Okenwa 2003. "Warri Refinery Shut Down, PENGASSAN Threatens Fresh Strike.” This Day (Lagos), March 27.

OKON, Emem and Doifie Ola 2002. "A Report of the Niger Delta Women Justice (NDWJ) on the Delta Women Siege on the American Oil Company, Chevron-Texaco in Delta State of Nigeria.” Port Harcourt: Niger Delta Women for Justice.

OKONTA, Ike and Oronto Douglas 2001. Where Vultures Feast: Shell, Human Rights, and Oil in the Niger Delta. San Francisco: Sierra Club Books.

OSOUKA, Asume, Esperanza Martnez, and Leila Salazar 2002. "Boycott ChevronTexaco." OilWatch, September 26. Available at (www.corpwatch.org).

OTHER SHELL REPORT 2003. Failing the Challenge: The Other Shell Report 2002. London: Friends of the Earth. 
OYAWIRI, Luke 2003. "Rivers Hostages: Britons May Take Legal Action.” This Day (Lagos), May 14.

PERKINS, Ellie 2002. "Markets or Discourse? A Green Feminist Alternative Value Process." Women and Environments 54/55(Spring): 15-18.

PLATTS 2003. "Vienna." Platts Oilgram, July 31.

ROSEN, Ruth 2003. "Peace Buffs.” San Francisco Chronicle, February 18.

SALA-I-MARTIN, Xavier and Arvind Subramanian 2003. "Addressing the Natural Resource Curse: An Illustration from Nigeria." IMF Working Paper WP/03/139, July. Washington, D.C.: IMF.

SARO-WIWA, Ken 1995. "Shell is Here on Trial: Pre-Conviction Statement to the Justice Auta Tribunal." In Where Vultures Feast: Shell, Human Rights, and Oil in the Niger Delta, by Ike Okonta and Oronto Douglas 2001. San Francisco: Sierra Club Books.

TANZER, Michael 2001. "Solidarity at the Pump: A Proposal for the Oil Exporting Nations of the Third World." NACLA Report on the Americas XXXIV(4)January, February: 17-24.

TURNER, Terisa E. 1997. "Oil Workers and Oil Communities in Africa: Nigerian Women and Grassroots Environmentalism." Labour, Capital and Society 30(1): 66-89. TURNER, Terisa E. 2001. "Shell's Ecocide in Nigeria." COMER (The Journal of the Committee on Monetary and Economic Reform) 13(12): 11-12.

TURNER, Terisa E. and Leigh S. Brownhill 2001. "Gender, Feminism and the Civil Commons: Women and the Anti-corporate, Anti-war Movement for Globalization from Below." Canadian Journal of Development Studies XXII(Special Issue): 805-18.

TURNER, Terisa E. et al. 2001. "Fightback from the Commons: Petroleum Industry and Environmental Racism." United Nations World Conference Against Racism, Racial Discrimination, Xenophobia and Related Intolerance, Durban, South Africa, August 31-September 7.

UNITED NATIONS, INTEGRATED REGIONAL INFORMATION NETWORK (IRIN) 2002. "Nigeria: Woman Shot Dead During Protest at Transnationals' Offices." United Nations Office for the Coordination of Humanitarian Affairs, August 15.

VANGUARD 2003. "Tit-Bits.” Vanguard (Lagos), July 10.

VIDAL, John 2003. "Oil Rig Hostages Are Freed by Strikers as Mercenaries Fly Out." The Guardian, May 3.

WAMALA, Irene 2002. "Nigerian Women Take on the Oil Companies." Women and Environments 56/57(Fall): 38.

Terisa E. Turner is Associate Professor of Sociology and Anthropology at the University of Guelph in Ontario, Canada. She is a co-founder of First Woman: The East and Southern African Women's Oral History and Indigenous Knowledge Network and co-director of the International Oil Working Group, a nongovernmental organization registered at the United Nations in New York. Her 
books include: Arise Ye Mighty People! Gender, Class and Race in Popular Struggles (1994) and Oil and Class Struggle (1980). In 2001 she co-edited with Leigh S. Brownhill, a special issue of the Canadian Journal of Development Studies on Gender, Feminism and the Civil Commons.

Address: Departments of Sociology and Anthropology, University of Guelph, 609 MacKinnon Building, Guelph, Ontario, N1G 2W1, Canada. (terisatu@uoguelph.ca)

Leigh S. Brownhill is a $\mathrm{PhD}$ candidate at the University of Toronto. She is the co-founder of First Woman: The East and Southern African Women's Oral History and Indigenous Knowledge Network and the co-director of the International Oil Working Group, a non-governmental organization registered with the Department of Public Information at the United Nations Secretariat in New York. In 2001 she co-edited with Terisa Turner, a special issue of the Canadian Journal of Development Studies on Gender, Feminism and the Civil Commons. Address: Department of Adult Education \& Community Development, Ontario Institute for Studies in Education, University of Toronto, 252 Bloor Street, Toronto, Ontario, M5S 1V6, Canada. (lbronhi@uoguelph.ca) 